\title{
INTERNET OF THINGS UNTUK MONITORING GEJALA KECEMASAN PADA PASIEN MENGGUNAKAN LOGIKA FUZZY
}

\author{
Muh. Sakir ${ }^{1}$, Indah Purwitasari Ihsan ${ }^{2 *}$, Farida Yusuf ${ }^{3}$ \\ ${ }^{1,2}$ Program Studi Teknik Elektro \\ Fakultas Teknik Universitas Fajar Makassar \\ Jl. Prof. Dr. H. Abdurrahman Basalamah, Makassar, Sulawesi Selatan. 90231 \\ *E-mail: indah.ihsan13@gmail.com \\ ${ }^{3}$ Jurusan Sistem Informasi \\ Fakultas Sains dan Teknologi UIN Alauddin Makassar \\ Jl. Sultan Alauddin No. 63, Gowa, Sulawesi Selatan. 92113
}

\begin{abstract}
Abstrak: Seorang pasien tidak boleh berada dalam kondisi psikologis yang cemas karena kecemasan justru akan menurunkan imunitas yang menyebabkan proses penyembuhan menjadi lambat bahkan berlangsung lama. Kecemasan yang berlarut akan berkembang menjadi stres, maka sangat perlu untuk dapat mendeteksi gejala kecemasan sejak dini, sebelum terjadi kecemasan yang berlarut dan berakibat stres. Namun gejala kecemasan ini berkaitan dengan faktor psikologis yang samar dan mengandung ketidakpastian yang tidak selalu bisa untuk dikontrol dan dimonitoring oleh dokter. Tujuan dari penelitian ini adalah membuat sistem yang dapat memonitoring gejala kecemasan pasien secara real time berbasis Internet of Things (IoT) sehingga dokter bisa menentukan treatment yang tepat untuk menjaga kondisi psikologis pasien. Sistem mendeteksi respon fisiologis pada manusia ketika seseorang merasa cemas yaitu perubahan detak jantung, suhu tubuh, dan intensitas keringat yang dideteksi menggunakan sensor. Informasi yang diperoleh dari sensor tersebut menjadi parameter input yang kemudian diolah menggunakan logika fuzzy untuk deteksi dini gejala kecemasan. Logika fuzzy dipilih karena merupakan metode untuk menyelesaikan masalah yang samar dengan ketidakpastian dari ambang batas nilai perubahan gejala. Output berupa gejala kecemasan yang dibagi menjadi 3 (tiga) gejala yaitu normal, ringan, dan berat. Metode penelitian yang digunakan adalah metode SDLC (System Development Life-Cycle). Berdasarkan hasil pengujian black box menyatakan seluruh fungsional sistem bekerja sesuai fungsinya, hasil pengujian white box menyatakan semua logika telah benar dan sesuai. Hasil penelitian menunjukkan bahwa sistem yang telah dibangun berhasil memonitoring gejala kecemasan pada pasien dengan tingkat akurasi sistem sebesar $98 \%$
\end{abstract}

Kata Kunci: gejala kecemasan, internet of things, logika fuzzy, pasien

\section{PENDAHULUAN}

$\mathbf{K}$

ondisi sekarang masih berada pada kondisi pandemi covid-19, yang mengharuskan kita untuk dapat selalu menjaga kesehatan, baik kesehatan fisik maupun kesehatan mental. Kesehatan mental berperan penting dalam menciptakan imunitas tubuh untuk menjaga kesehatan fisik maupun untuk penyembuhan penyakit. Faktor penting untuk mempercepat kesembuhan seorang pasien, selain mengonsumsi obat, vitamin dan makanan bergizi adalah dengan meningkatkan imunitas 
untuk melawan segala virus dan penyakit yang menyerangnya. Salah satu cara untuk meningkatkan dan menjaga imunitas, pasien harus bahagia dan positive thinking, pasien tidak boleh berada dalam kondisi psikologis yang cemas karena kecemasan justru akan menurunkan imunitas pasien, yang menyebabkan proses penyembuhan menjadi lambat bahkan berlangsung lama. Menurut kamus Kesehatan (Kementerian Kesehatan Republik Indonesia, 2013), cemas merupakan penyakit yang mengacu pada semua diagnosa gangguan kejiwaan atau mental dan ditandai oleh kelainan dalam pemikiran, perasaan, atau perilaku.

Kecemasan yang berlarut akan berkembang menjadi stres, oleh karena itu gejala kecemasan harus dideteksi sejak dini, agar dokter, perawat, maupun keluarga dapat memonitor gejala kecemasan sehingga dapat membantu mengatasi gejala tersebut dan memberi treatment yang tepat, agar imunitas pasien terjaga karena mentalnya sehat. Monitoring merupakan kegiatan mengawasi/pemantauan terhadap suatu objek yang bertujuan untuk mendapatkan informasi secara terus menerus. Monitoring merupakan kata serapan dari bahasa inggris, asal katanya adalah monitor yang artinya menurut Kamus Besar Bahasa Indonesia (KBBI) adalah memantau (KBBI, 2016). Namun tidak setiap saat dokter maupun perawat dapat memonitoring hal tersebut. Perkembangan teknologi jaringan memungkinkan kita untuk melakukan monitoring dari jarak jauh secara real time, salah satu teknologi tersebut adalah Internet of Things (IoT). Internet of things (IoT) is a concept that describes a network of interconnected devices which has advanced capabilities to interact with devices and also with human beings and its surrounding physical world to perform a variety of tasks(Bari et al., 2013).

Kecemasan bukanlah penyakit fisik yang dapat diketahui dengan pasti oleh dokter, kecemasan merupakan gangguan mental yang kadang tidak terlihat gejalanya karena samar, maka untuk dapat mendeteksinya dibutuhkan metode untuk menyelesaikan masalah yang samar dengan ketidakpastian tersebut, metode yang bisa digunakan yaitu logika fuzzy. Logika fuzzy adalah suatu logika yang memiliki nilai kesamaran antara benar atau salah. Logika fuzzy dapat digunakan untuk menyelesaikan masalah ketidakpastian, serta ketidaktepatan. A fuzzy logic provides an inference mechanism that allows us to simulate human reasoning into knowledge-based systems. The theory of fuzzy logic provides a mathematical framework that allows modeling the uncertainty of human cognitive processes in a way that can be treatable by a computer (Pamuji, 2016).

Kecemasan dapat menyebabkan respon sistem kardiovaskuler, antara lain palpitasi, jantung berdebar, rasa ingin pingsan, penurunan tekanan darah dan penurunan denyut nadi (Hastuti \& Mulyani, 2019). Denyut nadi merupakan bagian dari sistem kerja jantung, sehingga pada keadaan jantung yang berdebar-debar dalam teori yang dikemukakan oleh para ahli psikologis merupakan salah satu wujud gejala fisik pada kecemasan tingkat fisiologis (Pontoh et al., 2015). Gejala fisik atau gejala fisiologis pada gangguan kecemasan antara lain berupa jantung berdetak lebih cepat, otot- otot yang mengencang, meningkatnya tekanan darah, napas terengah-engah atau memburu, dan indera yang ada di tubuh menjadi lebih tajam, mudah lelah, dan sering berkeringat. Gejala tersebut dapat diukur menggunakan alat ukur kesehatan, seiring dengan berkembangnya teknologi, perubahan fisiologis dapat dideteksi dengan menggunakan sensor. Parameter yang akan diukur menggunakan sensor pada penelitian ini adalah perubahan pada detak jantung, suhu tubuh dan denyut nadi. Hasil dari pengukuran tersebut akan menjadi parameter input untuk diolah menggunakan logika fuzzy sehingga menghasilkan parameter output berupa tingkatan gejala kecemasan yaitu normal, ringan, atau berat. 
Sistem ini akan diujicobakan kepada pasien yang tidak memiliki riwayat penyakit seperti hipertensi, arteri koroner, serangan jantung, dan mempunyai jantung lemah serta pasien tidak dalam keadaan setelah beraktivitas berat atau berolahraga. Kesemua rangkaian sistem akan diintegrasikan dengan teknologi jaringan komunikasi yang saat ini sedang berkembang dan banyak dimanfaatkan untuk kemajuan di berbagai bidang yaitu Internet of Things. Sehingga nantinya gejala kecemasan seorang pasien bisa terdeteksi sejak dini dan dapat dimonitoring secara terus menerus.

\section{METODE PENELITIAN}

Metode merupakan cara untuk mencapai tujuan penelitian yang telah peneliti tetapkan. Metode pada penelitian ini yaitu menggunakan metode System Development Life-Cycle (SDLC) yang terdiri dari lima tahapan (Damopolii M., 2016) yaitu:

1. Tahapan requirement analysis

Pada tahap ini akan dilakukan studi kelayakan dari penelitian yang akan dibuat dengan cara studi literatur, diskusi bersama tim peneliti dan sharing bersama pakar. Pada tahap ini juga akan dilakukan analisa kebutuhan dan persyaratan dari alat yang akan dibuat kemudian dituangkan dalam dokumen System Requirement Specification (SRS). Pada tahap ini juga termasuk mengumpulkan data dan membuat instrumen pengujian dan validasi.

2. Tahapan system design

Pada tahap ini akan dibuat perancangan konseptual dan perancangan logis berupa flowchart sistem serta blok diagram alat, perancangan interaksi sistem menggunakan UML serta perancangan user interface, serta membuat perancangan fisik.

3. Tahapan implementation

Pada tahap ini merupakan tahap pembuatan alat dengan mengimplementasikan seluruh rancangan yang telah dibuat pada tahap sebelumnya.

4. Tahapan testing

Alat yang telah dibuat akan diujicobakan untuk mengevaluasi dan menemukan kekurangan dan kesalahan dari alat tersebut Teknik uji coba menggunakan metode black box testing, white box testing dan pengujian oleh pakar untuk memastikan alat tersebut dapat berjalan sesuai rancangan dan tujuan.

5. Tahapan operation and maintenance

Tahap ini adalah tahapan untuk memperbaiki kekurangan dan kesalahan yang ditemukan pada tahap pengujian.

\section{HASIL DAN PEMBAHASAN \\ Unified Modelling System (UML)}

Salah satu diagram UML adalah diagram use case. Use Case Diagram menggambarkan hubungan interaksi antara user dengan sistem dengan urutan langkahlangkah dan fungsinya (Sonata \& Sari, 2019). User terbagi tiga yaitu admin, petugas kesehatan (dokter dan perawat), dan pasien. Diagram use case-nya ditunjukkan pada Gambar 1. 


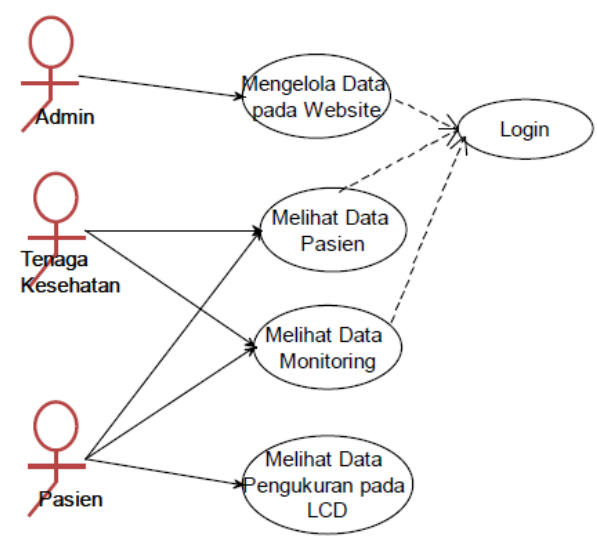

Gambar 1. Diagram use case

\section{Flowchart System}

Flowchart merupakan penggambaran alur sistem secara sistematis yang digambarkan dalam bentuk began (Santoso \& Nurmalina, 2017). Flowchart system ditunjukkan pada Gambar 2.

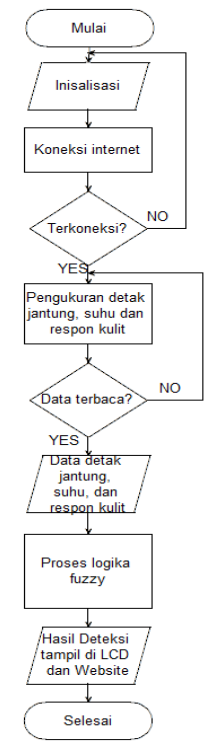

Gambar 2. Flowchart System

\section{Blok Diagram Sistem}

Blok diagram sistem menggambarkan komponen-komponen hardware yang bekerja secara terintegrasi dalam membentuk suatu sistem kerja alat (Susana et al., 2017). Blok diagram alat ditunjukkan pada Gambar 3.

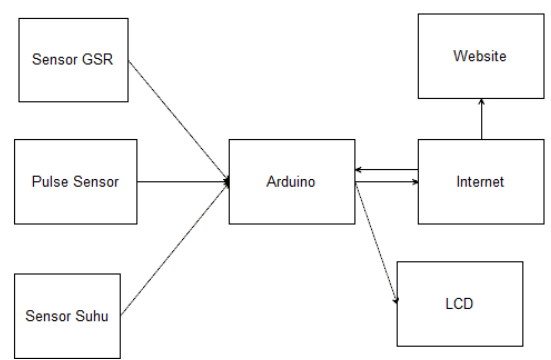

Gambar 3. Blok diagram alat 


\section{Perancangan Alat Deteksi}

Diagram komponen alat yang digunakan pada rangkaian deteksi kondisi fisiologis pasien ditunjukkan pada Gambar 4.

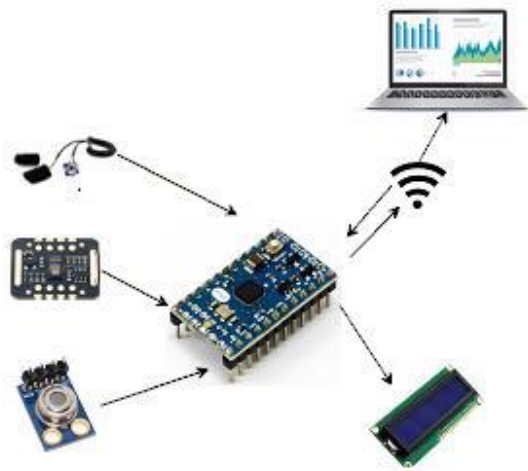

Gambar 4. Komponen alat

Alat deteksi akan dibuat menyerupai jam, sehingga mudah digunakan (Gambar 5).
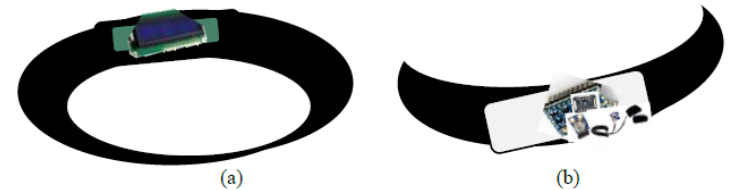

Gambar 5. Rancangan prototipe (a) tampak atas dan (b) tampak bawah

\section{Perancangan User Interface Website Monitoring}

Hasil pembacaan sensor menjadi parameter input yang akan diolah oleh logika fuzzy untuk kemudian hasilnya ditampilkan dalam sebuah website yang bias diakses oleh perawat, dokter maupun pasien itu sendiri. Rancangan user interface dari website monitoring ditunjukkan pada Gambar 6.
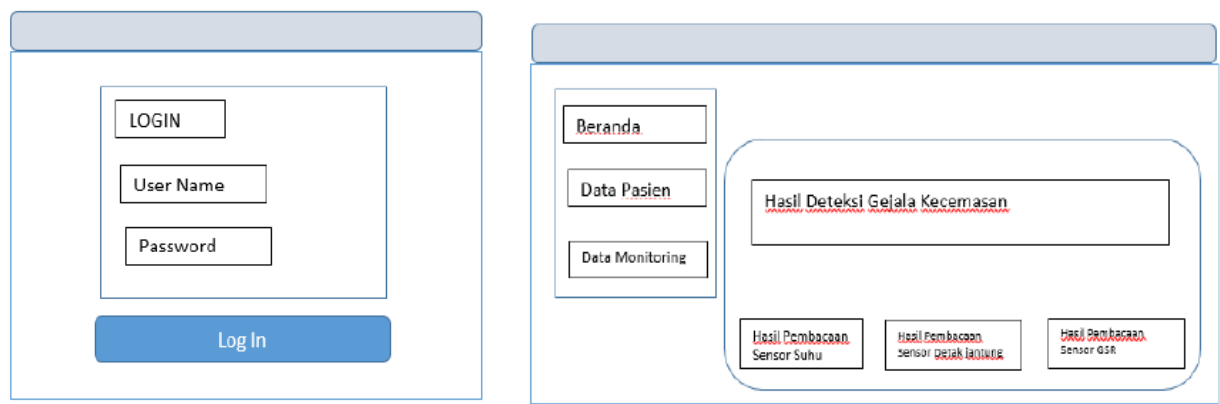

Gambar 6. Perancangan user interface website monitoring

\section{Proses Logika Fuzzy}

Parameter yang digunakan untuk mendeteksi gejala kecemasan yang akan diolah menggunakan logika fuzzy meliputi: 


\section{Parameter tingkat stres}

Tabel 1. Parameter tingkat stres pada usia lebih dari 17 tahun

\begin{tabular}{cccc}
\hline Kondisi & $\begin{array}{c}\text { Detak Jantung } \\
(\mathbf{b p m})\end{array}$ & Suhu Tubuh $\left({ }^{\circ} \mathbf{C}\right)$ & $\begin{array}{c}\text { Respon Kulit terhadap } \\
\text { Kelenjar Keringat (Siemens) }\end{array}$ \\
\cline { 2 - 4 } & $60-90$ & $35-37$ & $<4$ \\
Normal & $90-100$ & $33-35$ & $4-6$ \\
Ringan & $>100$ & $<33$ & $>6$ \\
Berat/Stres & & & \\
\hline
\end{tabular}

2. Parameter detak jantung

Tabel 2. Parameter detak jantung

\begin{tabular}{ll}
\hline Kondisi & Detak Jantung $(\mathbf{b p m})$ \\
\hline Lambat & $<80$ \\
Normal & $70-100$ \\
Cepat & $>90$ \\
\hline
\end{tabular}

Gambar 7 menunjukkan himpunan fuzzy detak jantung.

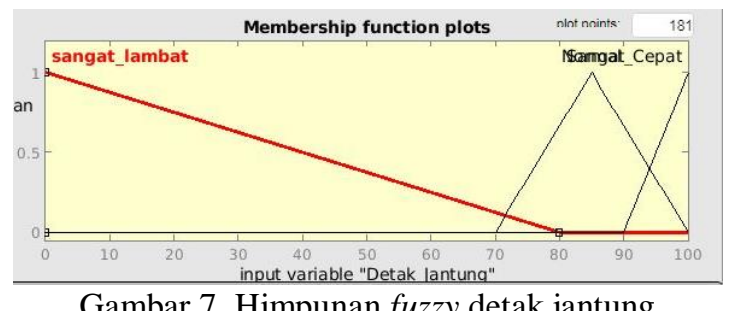

Gambar 7. Himpunan fuzzy detak jantung

3. Parameter suhu tubuh

Tabel 3. Parameter suhu tubuh

\begin{tabular}{cc}
\hline Kondisi & Suhu tubuh $\left({ }^{\circ} \mathbf{C}\right)$ \\
\hline Panas & $>35.1$ \\
Normal & $32.5-36.4$ \\
Dingin & $<33$ \\
\hline
\end{tabular}

Berikut merupakan himpunan Fuzzy suhu tubuh

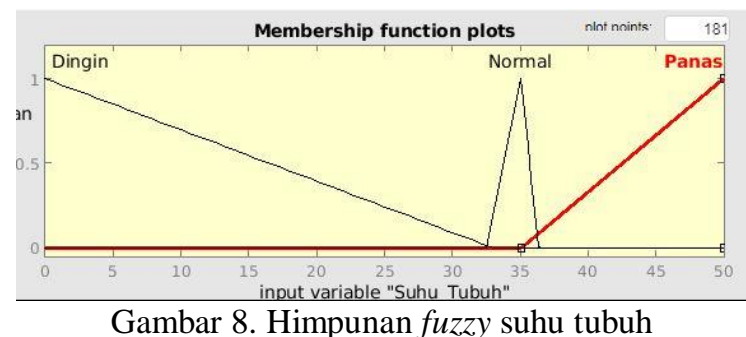

4. Parameter respon kulit

Tabel 4. Parameter respon kulit

\begin{tabular}{ll}
\hline Kondisi & Respon kulit terhadap kelenjar keringat (Siemens) \\
\hline Kering & $<3$ \\
Normal & $2-5$ \\
Basah & $>4$ \\
\hline
\end{tabular}


Himpunan fuzzy respon kulit terhadap kelenjar keringat ditunjukkan pada Gambar 9.

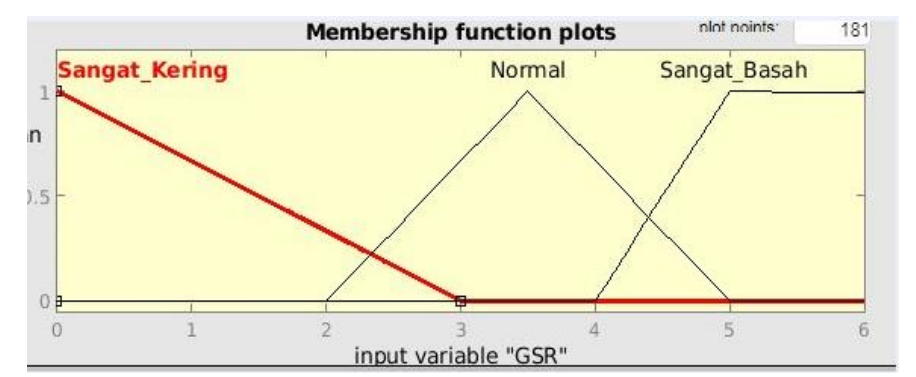

Gambar 9. Himpunan fuzzy respon kulit terhadap kelenjar keringat

\section{Implementasi Sistem}

Implementasi sistem merupakan kegiatan menenerapkan seluruh rancangan yang telah dibuat sebelumnya untuk mengembangkan prototipe/sistem.

1. Alat pendeteksi respon fisiologis

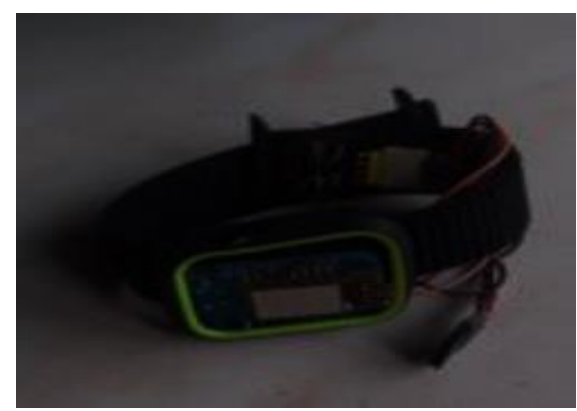

Gambar 10. Alat pendeteksi respon fisiologis

2. Website monitoring

Website monitoring dapat diakses pada alamat URL http://monitoringku.id/.

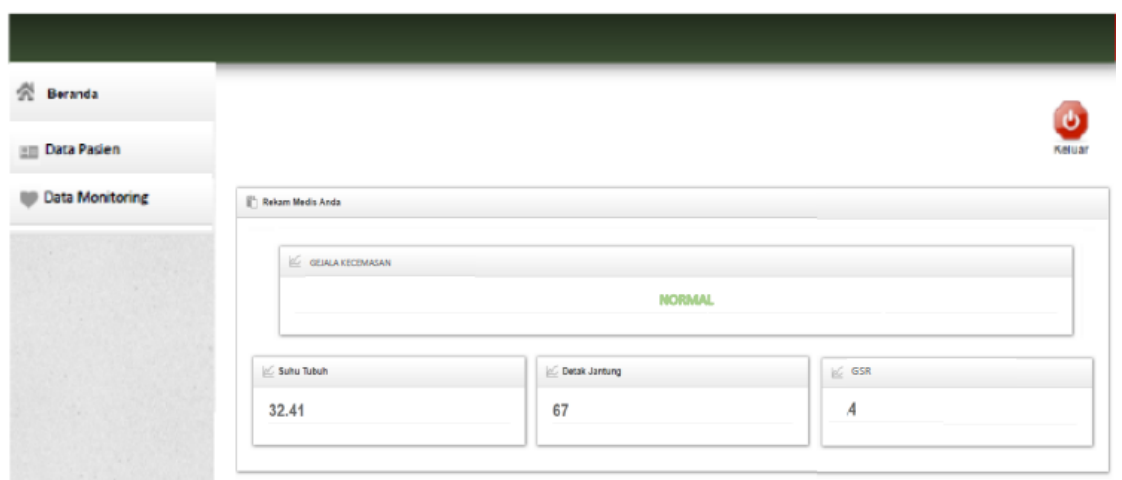

Gambar 11. Halaman data monitoring

\section{Pengujian}

Pengujian dilakukan dalam beberapa tahap, meliputi:

1. Pengujian akurasi sensor

a. Pengujian akurasi sensor detak jantung

Hasil pengujian akurasi sensor jantung ditunjukkan pada Tabel 5. Berdasarkan hasil pengujian menunjukkan bahwa akurasi sensor detak jantung adalah 97,6\%. 
Tabel 5. Hasil pengujian akurasi sensor detak jantung

\begin{tabular}{cccccc}
\hline \multirow{2}{*}{ Pengujian Ke- } & \multicolumn{2}{c}{ Detak Jantung (BPM) } & Error & Error \% & Akurasi \\
\cline { 2 - 6 } & Tensimeter & Sensor & $\begin{array}{c}\text { (Nilai Acuan - } \\
\text { Nilai Pengukuran) }\end{array}$ & $\begin{array}{c}\text { (Error/Nilai Acuan } \\
\text { x 100) }\end{array}$ & $\%$ \\
\hline 1 & 90 & 90 & 0 & 0.00 & 100.0 \\
3 & 75 & 76 & 1 & 1.33 & 98.7 \\
4 & 78 & 78 & 0 & 0.00 & 100.0 \\
5 & 66 & 65 & 1 & 1.52 & 98.5 \\
6 & 65 & 74 & 9 & 13.85 & 86.2 \\
7 & 94 & 96 & 2 & 2.13 & 97.9 \\
8 & 77 & 74 & 3 & 3.90 & 96.1 \\
9 & 78 & 77 & 1 & 1.28 & 98.7 \\
10 & 80 & 80 & 0 & 0.00 & 100.0 \\
Rata-rata & 79.5 & 80.4 & 2 & 2.17 & 97.8 \\
Akurasi (\%) & & 94 & 1.9 & 2.39 & 97.6 \\
\hline
\end{tabular}

b. Pengujian akurasi sensor suhu

Hasil pengujian akurasi sensor suhu ditunjukkan pada Tabel 6. Berdasarkan hasil pengujian menunjukkan bahwa akurasi sensor suhu adalah $99.6 \%$

Tabel 6. Hasil pengujian akurasi sensor suhu

\begin{tabular}{cccccr}
\hline \multirow{2}{*}{ Pengujian Ke-- } & \multicolumn{2}{c}{ Suhu Tubuh $\left({ }^{\circ} \mathrm{C}\right)$} & Error & Error \% & Akurasi \\
\cline { 2 - 6 } & Termometer & Sensor & $\begin{array}{c}\text { (Nilai Acuan-Nilai } \\
\text { Pengukuran) }\end{array}$ & $\begin{array}{c}\text { (Error/Nilai Acuan } \\
\text { X 100) }\end{array}$ & $\%$ \\
\hline 1 & 36.7 & 36.4 & 0.3 & 0.82 & 99.2 \\
2 & 36.2 & 36.8 & 0.6 & 1.66 & 98.3 \\
3 & 36.4 & 36.6 & 0.2 & 0.55 & 99.5 \\
4 & 36.7 & 36.7 & 0 & 0.00 & 100.0 \\
5 & 36.5 & 36.6 & 0.1 & 0.27 & 99.7 \\
6 & 36.7 & 36.8 & 0.1 & 0.27 & 99.7 \\
7 & 36.8 & 36.8 & 0 & 0.00 & 100.0 \\
8 & 36.4 & 36.4 & 0 & 0.00 & 100.0 \\
9 & 36.5 & 36.6 & 0.1 & 0.27 & 99.7 \\
10 & 36.7 & 36.7 & 0 & 0.00 & 100.0 \\
Rata-rata & 36.56 & 36.64 & 0.14 & 0.38 & 99.62 \\
Akurasi $(\%)$ & & & $\mathbf{9 9 . 6 \%}$ & & \\
\hline
\end{tabular}

c. Pengujian akurasi sensor GSR

Hasil pengujian akurasi sensor GSR ditunjukkan pada Gambar 8. Berdasarkan hasil pengujian menunjukkan bahwa akurasi sensor GSR adalah $86,7 \%$ 
Tabel 8. Hasil pengujian akurasi sensor GSR

\begin{tabular}{cccccr}
\hline \multirow{2}{*}{ Pengujian Ke- } & \multicolumn{2}{c}{ Respon Kulit } & Error & Error \% & Akurasi \\
\cline { 2 - 6 } & $\begin{array}{c}\text { high frequency } \\
\text { galvanic vac spray }\end{array}$ & Sensor & $\begin{array}{c}\text { (Nilai Acuan - } \\
\text { Nilai Pengukuran) }\end{array}$ & $\begin{array}{r}\text { (Error/Nilai } \\
\text { Acuan x 100) }\end{array}$ & $\%$ \\
\hline 1 & 3 & 3 & 0 & 0.00 & 100.0 \\
2 & 3 & 4 & 1 & 33.33 & 66.7 \\
3 & 2 & 4 & 2 & 100.00 & 0.0 \\
4 & 3 & 3 & 0 & 0.00 & 100.0 \\
5 & 5 & 5 & 0 & 0.00 & 100.0 \\
6 & 2 & 3 & 1 & 50.00 & 50.0 \\
7 & 2 & 2 & 0 & 0.00 & 100.0 \\
8 & 4 & 4 & 0 & 0.00 & 100.0 \\
9 & 3 & 3 & 0 & 0.00 & 100.0 \\
10 & 3 & 3 & 0 & 0.00 & 100.0 \\
Rata-rata & 3 & 3.4 & 0.4 & 13.33 & 86.67 \\
Akurasi $(\%)$ & & & $86.7 \%$ & & \\
\hline
\end{tabular}

2. Pengujian fungsional

Hasil dari pengujian fungsional sebanyak 5 kali menunjukkan bahwa semua fungsi berjalan dengan baik sesuai yang diharapkan dengan tingkat keberhasilan 100\%. Data hasil pengujian fungsional ditunjukkan pada Tabel 9.

Tabel 9. Hasil pengujian fungsional

\begin{tabular}{|c|c|c|c|c|c|c|c|c|c|c|c|c|c|c|c|c|c|c|c|c|c|c|c|c|c|c|}
\hline \multirow{3}{*}{$\begin{array}{c}\text { Pengujian } \\
\text { Ke- }\end{array}$} & \multicolumn{26}{|c|}{ Deskripsi Fungsional } \\
\hline & \multicolumn{2}{|c|}{1} & \multicolumn{2}{|c|}{2} & \multicolumn{2}{|r|}{3} & \multicolumn{2}{|c|}{4} & \multicolumn{2}{|c|}{5} & \multicolumn{2}{|c|}{6} & \multicolumn{2}{|c|}{7} & \multicolumn{2}{|c|}{8} & \multicolumn{2}{|r|}{9} & \multicolumn{2}{|c|}{10} & \multicolumn{2}{|c|}{11} & \multicolumn{2}{|c|}{12} & \multicolumn{2}{|c|}{13} \\
\hline & B & $\mathrm{T}$ & B & $\mathrm{T}$ & B & $\mathrm{T}$ & B & $\mathrm{T}$ & B & $\mathrm{T}$ & B & $\mathrm{T}$ & B & $\mathrm{T}$ & B & $\mathrm{T}$ & B & $\mathrm{T}$ & B & $\mathrm{T}$ & B & $\mathrm{T}$ & B & $\mathrm{T}$ & $\mathrm{B}$ & $\mathrm{T}$ \\
\hline 1 & $\sqrt{ }$ & & $\sqrt{ }$ & & $\sqrt{ }$ & & $\sqrt{ }$ & & $\sqrt{ }$ & & $\sqrt{ }$ & & $\sqrt{ }$ & & $\sqrt{ }$ & & $\sqrt{ }$ & & $\sqrt{ }$ & & $\sqrt{ }$ & & $\sqrt{ }$ & & $\sqrt{ }$ & \\
\hline 2 & $\sqrt{ }$ & & $\sqrt{ }$ & & $\sqrt{ }$ & & $\sqrt{ }$ & & $\sqrt{ }$ & & $\sqrt{ }$ & & $\sqrt{ }$ & & $\sqrt{ }$ & & $\sqrt{ }$ & & $\sqrt{ }$ & & $\sqrt{ }$ & & $\sqrt{ }$ & & $\sqrt{ }$ & \\
\hline 3 & $\sqrt{ }$ & & $\sqrt{ }$ & & $\sqrt{ }$ & & $\sqrt{ }$ & & $\sqrt{ }$ & & $\sqrt{ }$ & & $\sqrt{ }$ & & $\sqrt{ }$ & & $\sqrt{ }$ & & $\sqrt{ }$ & & $\sqrt{ }$ & & $\sqrt{ }$ & & $\sqrt{ }$ & \\
\hline 4 & $\sqrt{ }$ & & $\sqrt{ }$ & & $\sqrt{ }$ & & $\sqrt{ }$ & & $\sqrt{ }$ & & $\sqrt{ }$ & & $\sqrt{ }$ & & $\sqrt{ }$ & & $\sqrt{ }$ & & $\sqrt{ }$ & & $\sqrt{ }$ & & $\sqrt{ }$ & & $\sqrt{ }$ & \\
\hline 5 & $\sqrt{ }$ & & $\sqrt{ }$ & & $\sqrt{ }$ & & $\sqrt{ }$ & & $\sqrt{ }$ & & $\sqrt{ }$ & & $\sqrt{ }$ & & $\sqrt{ }$ & & $\sqrt{ }$ & & $\sqrt{ }$ & & $\sqrt{ }$ & & $\sqrt{ }$ & & $\sqrt{ }$ & \\
\hline Total Hasil & & 0 & 5 & 0 & 5 & 0 & 5 & 0 & 5 & 0 & 5 & 0 & 5 & 0 & 5 & 0 & 5 & 0 & 5 & 0 & 5 & 0 & 5 & 0 & 5 & 0 \\
\hline Tingkat Keb & perh & lasil & an: 1 & 100 & & & & & & & & & & & & & & & & & & & & & & \\
\hline
\end{tabular}

3. Pengujian White Box

Flowgraph yang menampilkan data hasil deteksi ditunjukkan pada Gambar 12. Perhitungan kompleksitas siklomatis:

$\mathrm{V}(\mathrm{G})=10$ edge -9 node $+2=3$

Dengan demikian kompleksitas siklomatis dari flow graph adalah 3. Dengan jalur independennya adalah: Jalur 1: 1-2-3-4-5-6-7-8-9; Jalur 2: 1-2-3-2-3-4-5-6-7-8-9; dan Jalur 3: 1-2-3-4-5-4-5-6-7-8-9. 


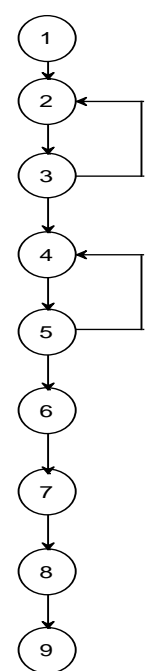

Gambar 12. Flowgraph sistem monitoring

\section{Validasi ahli}

Pengujian dilakukan oleh seorang psikolog menggunakan instrument DASS42. Hasil validasi ahli ditunjukkan pada Tabel 10.

Tabel 10. Hasil validasi ahli

\begin{tabular}{clll}
\hline Sampel & Psikolog dengan instrumen DSAS & Alat & Hasil \\
& & & \\
\hline 1 & Normal & Normal & Sesuai \\
2 & Normal & Ringan & Tidak Sesuai \\
3 & Ringan & Ringan & Sesuai \\
4 & Normal & Normal & Sesuai \\
5 & Normal & Normal & Sesuai \\
6 & Ringan & Ringan & Sesuai \\
7 & Ringan & Ringan & Sesuai \\
8 & Normal & Normal & Sesuai \\
9 & Ringan & Berat & Tidak Sesuai \\
10 & Normal & Normal & Sesuai \\
Akurasi & 98\% & & \\
\hline
\end{tabular}

Hasil dari pengujian menunjukkan bahwa dari 10 kali pengujian terhadap pasien diperoleh hasil deteksi antara alat dengan intrumen DASS42 dengan 8 kondisi sesuai dan 2 kondisi tidak sesuai, maka diperoleh akurasi dari sistem monitorning berbasis internet of things menggunakan logika fuzzy adalah sebesar $98 \%$ akurat.

\section{KESIMPULAN}

Berdasarkan keseluruhan hasil pengujian menunjukkan bahwa semua fungsi telah berhasil berfungsi sesuai perancangan dan tujuan sistem. Hasil pengujian akurasi sensor detak jantung akurat sebesar 97,6\% dalam mengukur detak jantung pasien, sensor suhu akurat sebesar 99,6, serta sensor GSR akurat sebesar 86,7\%. Berdasarkan pengujian fungsional menunjukkan bahwa semua fungsi telah berjalan sesuai fungsinya dan 
memiliki tingkat keberhasilan sebesar 100\%. Hasil pengujian white box menunjukkan bahwa tidak ada kesalahan logika dan seluruh logika telah berjalan dengan benar. Hasil validasi ahli menunjukkan bahwa sistem yang telah dibuat $98 \%$ valid dan akurat.

\section{DAFTAR PUSTAKA}

Bari, N., Mani, G., \& S. Berkovich. (2013). Internet of Things as a Methodological Concept. Fourth International Conference on Computing for Geospatial Research and Application 2013. https://doi.org/10.1109/COMGEO.2013.8.

Damopolii, M.Y.M. (2016). Action Research Teori, Model dan Aplikasi. Jakarta: PT Fajar Interpratama Mandiri.

Hastuti, Y. D., \& Mulyani, E. D. (2019). Kecemasan pasien dengan penyakit jantung koroner. Jurnal Perawat Indonesia, 3(3), 167-174.

KBBI. (2016). Hasil Pencarian - KBBI Daring. Badan Pengembangan dan Pembinaan Bahasa, Kementerian Pendidikan dan Kebudayaan Republik Indonesia. https://kbbi.kemdikbud.go.id/entri/integrasi\%0Ahttps://kbbi.kemdikbud.go.id/entri/pendidikan.

Kementerian Kesehatan Republik Indonesia. (2013). Arti Kecemasan. Kemkes.go.id.

Pamuji, A. (2016). Assessment the method of fuzzy logic to determine the quality of service expedition in Jabodetabek Area. Scientific Journal of Informatics, 3(2), 109-118. https://doi.org/10.15294/sji.v3i2.7906.

Pontoh, B. I., Pangemanan, D. H. C., \& Mariati, N. W. (2015). Hubungan tingkat kecemasan dengan perubahan denyut nadi pada pasien ekstraksi gigi di Puskesmas Tuminting Manado. Jurnal e-GiGi $(e G), 3(1), 13-17$.

Santoso, S., \& Nurmalina, R. (2017). Perencanaan dan pengembangan aplikasi absensi mahasiswa menggunakan smart card guna pengembangan kampus cerdas (Studi kasus Politeknik Negeri Tanah Laut). Jurnal Integrasi, 9(1), 84-91.

Sonata, F., \& F.M. Sari. (2019). Pemanfaatan UML (Unified Modeling Language) dalam perancangan sistem informasi e-commerce jenis customer-to-customer. Jurnal Komunika: Jurnal Komunikasi, Media dan Informatika, 8(1), 22-31. https://doi.org/10.31504/komunika.v8i1.1832.

Susana, R., Albayumi, U. A., \& Bugar, F. S. (2017). Implementasi function block diagram pada simulator kontrol landing gear system untuk roda pesawat. Jurnal Elektro dan Telekomunikasi Terapan, 3(2), 322-331. https://doi.org/10.25124/jett.v3i2.301. 